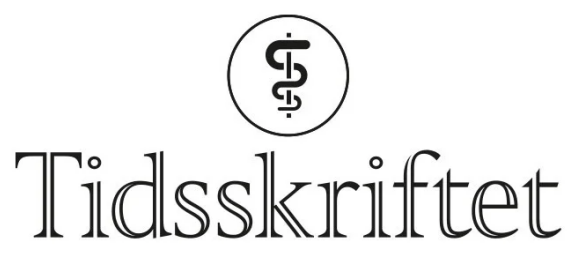

DEN NORSKE LEGEFORENING

\title{
Hurtigtesting for SARS-CoV-2-virus gir falsk trygghet
}

LEDER

\section{ELLING ULVESTAD}

elling.ulvestad@helse-bergen.no

Elling Ulvestad er avdelingssjef ved Mikrobiologisk avdeling, Haukeland universitetssjukehus og professor ved Klinisk institutt 2, Universitetet i Bergen.

Forfatteren har fylt ut ICMJE-skjemaet og oppgir ingen interessekonflikter.

\section{ØYVIND KOMMEDAL}

Øyvind Kommedal er seksjonsoverlege ved Mikrobiologisk avdeling, Haukeland universitetssjukehus og førsteamanuensis ved Klinisk institutt 2, Universitetet i Bergen. Forfatteren har fylt ut ICMJE-skjemaet og oppgir ingen interessekonflikter.

\section{Bruk av antigenhurtigtester for påvisning av SARS-CoV-2- virus kan gi falsk trygghet og økt smittespredning.}

I desember 2021 holdt Norge på å gå tom for antigenhurtigtester for SARS-CoV-2-virus, til tross for at norske helsemyndigheter hadde kjøpt inn mer enn ti millioner enheter. Ettersom bruk av hurtigtester kanskje kan avlaste behovet for mer inngripende smittevernsregimer, ble det raskt inngått kjøpsavtaler om 15 millioner hurtigtester og ytterligere 50 millioner tester med leveranse tidlig i 2022 (1). Testene er angitt å koste 30

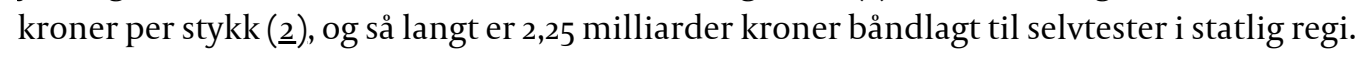
I januar 2022 ble ytterligere 5 milliarder kroner foreslått avsatt for innkjøp av selvtester. I tillegg kommer flere millioner selvtester solgt gjennom kommersielle kanaler.

Testing ved hjelp av antigenhurtigtester anbefales for alle som mistenker at de har vært utsatt for smitte, og til screening av skoleelever og studenter for å kunne holde skoler og universiteter åpne (3). Anbefalingen har en viss testteoretisk støtte: Epidemiologiske modeller tilsier at hurtigtester kan være effektive til å luke ut smittede i situasjoner med lav sykdomsprevalens (4). Vurderingen tar imidlertid ikke tilstrekkelig høyde for konsekvensene av et falskt negativt prøvesvar. Etter hvert som smitten øker, er det åpenbart at tester med lav sensitivitet vil «frikjenne» så mange smitteførende personer at virusspredningen uansett blir omfattende (5).

Antigenhurtigtestene har en sensitivitet på $79 \%$ hos symptomatiske og $55 \%$ hos asymptomatiske personer dersom testene utføres av trent helsepersonell (므). Selvtesting hjemme eller på skolen må antas å ha enda lavere sensitivitet. Modelleringsstudier har vist at repetert hyppig testing vil kunne fange opp mange av disse falskt negative tilfellene (7.), 
men grunnlaget for massetesting 1-2 ganger i uken, slik norske myndigheter tar til orde for, er vanskelig å forstå. Tiden fra siste negative PCR-test til maksimal virusutskillelse er tre døgn ( $\underline{8})$, og tiden til man er smitteførende, er enda kortere. Dette betyr at asymptomatiske elever vil ha rikelig rom for effektiv smittespredning mellom testene. Man hindrer ikke rømt oppdrettslaks fra å svømme opp en elv ved å sette ut et hullete garn to ganger i uken, for å bruke en metafor.

\section{«Man hindrer ikke rømt oppdrettslaks fra å svømme opp en elv ved å sette ut et hullete garn to ganger i uken»}

Gitt statlige innkjøp i milliardklassen, skulle man tro at antigenhurtigtestenes samfunnsmedisinske konsekvenser var avklart gjennom kostnad-nytte-betraktninger. Så langt foreligger ingen kontrollerte studier som kan bekrefte eller avkrefte testingens nytteverdi. Heller ikke finnes kunnskap om det motsatte - om testingen bidrar til økt smittespredning, slik enkelte massesmittehendelser indikerer (9.). Høsten 2021 steg smittetallene i Norge raskt som følge av spredning av deltavarianten av SARS-CoV-2-viruset. I hvor stor grad de mer enn ti millionene hurtigtester som ble brukt bidro til massespredning eller til å holde varianten i sjakk, står fortsatt uavklart.

Bruken av antigenhurtigtester er drevet fram av teoretiske betraktninger og epidemiologisk modellering, hvorav en av de mest betydningsfulle var utført av forskere med $ø$ konomiske bindinger til en av de største hurtigtestprodusentene (10). Inntil godt planlagte og vel gjennomførte empiriske studier er utført, står antigenhurtigtestenes samfunnsmedisinske betydning ubesvart. Storstilt bruk av antigenhurtigtester på et så pass svakt kunnskapsgrunnlag kan vanskelig forsvares, særlig fordi det ikke kan utelukkes at dagens bruk kan føre til mer - ikke mindre - smitte i samfunnet.

\section{LITTERATUR}

1. Olsen T. Fagfolk er skeptiske til halvparten av hurtigtestene. Bergens Tidende 15.12.2021. https://www.bt.no/nyheter/innenriks/i/WjeOG2/fagfolk-er-skeptiske-til-halvparten-av-hurtigtestene Lest 17.1.2022.

2. Sluttrapport. Pilotprosjekt: Jevnlig covid-19-testing med antigen hurtigtester av elever i videregående skoler. Bergen: Vestland fylkeskommune, 2021.

https://www.vestlandfylke.no/globalassets/om-oss/korona/sluttrapport_jevnlig-covid-testing-ivgs_vlfk.pdf Lest 17.1.2022.

3. Øverb $\emptyset$, Knudsen CV, Stefanoff P et al. Jevnlig SARS-Cov-2 testing med antigen-hurtigtester i utdanningsinstitusjoner våren 2021. Oslo: Folkehelseinstituttet, 2021.

https://www.fhi.no/globalassets/dokumenterfiler/rapporter/2021/jevnlig-testing-var-2021.pdf Lest 17.1.2022.

4. Peeling RW, Olliaro PL, Boeras DI et al. Scaling up COVID-19 rapid antigen tests: promises and challenges. Lancet Infect Dis 2021; 21: e290-5. [PubMed][CrossRef]

5. Fouzas S. SARS-CoV-2 rapid antigen detection tests. Lancet Infect Dis 2021; 21:1068-9. [PubMed] [CrossRef]

6. Landaas ET, Storm ML, Tollånes MC et al. Diagnostic performance of a SARS-CoV-2 rapid antigen test in a large, Norwegian cohort. J Clin Virol 2021; 137: 104789. [PubMed][CrossRef]

7. Paltiel AD, Zheng A, Walensky RP. Assessment of SARS-CoV-2 screening strategies to permit the safe reopening of college campuses in the United States. JAMA Netw Open 2020;3: e2016818. [PubMed] [CrossRef]

8. Singanayagam A, Hakki S, Dunning J et al. Community transmission and viral load kinetics of the SARS-CoV-2 delta (B.1.617.2) variant in vaccinated and unvaccinated individuals in the UK: a prospective, longitudinal, cohort study. Lancet Infect Dis 2021; 21: S1473-3099. [PubMed][CrossRef]

9. Brandal LT, MacDonald E, Veneti L et al. Outbreak caused by the SARS-CoV-2 Omicron variant in Norway, November to December 2021. Euro Surveill 2021; 26. doi: 10.2807/156o7917.ES.2021.26.50.2101147. [PubMed][CrossRef] 
10. Mina MJ, Parker R, Larremore DB. Rethinking Covid-19 Test Sensitivity - A Strategy for Containment. N Engl J Med 2020;383: e120. [PubMed][CrossRef]

Publisert: 18. januar 2022. Tidsskr Nor Legeforen. DOI:10.4045/tidsskr.22.00o9

(C) Tidsskrift for Den norske legeforening 2023. Lastet ned fra tidsskriftet.no 26. april 2023. 